\title{
Using Electrical Profiling to Determine Soil Petrophysical Parameters in an Agricultural Field
}

\author{
Ana Karen Gastélum-Contreras ${ }^{1}$, Mauro Espinoza-Ortiz ${ }^{2}$, \\ Héctor José Peinado-Guevara ${ }^{1,2 *}$, Omar Delgado-Rodríguez ${ }^{3}$, \\ María de los Ángeles Ladrón de Guevara ${ }^{4}$, \\ Víctor Manuel Peinado-Guevara ${ }^{1}$
}

${ }^{1}$ Escuela de Ciencias Económicas y Administrativas, Universidad Autónoma de Sinaloa,

Blvd. Juan de Dios Bátiz s/n, San Joachín, Guasave, Sinaloa, México

${ }^{2}$ Facultad de Ingeniería, Universidad Autónoma de Sinaloa, Fuente de Poseidón y Ángel Flores s/n, Jiquilpan, Los Mochis, Sinaloa, México.

${ }^{3}$ División de Geociencias Aplicadas, Instituto Potosino de Investigación Científica y Tecnológica Camino a la Presa San José 2055, Lomas 4 Sección, San Luis Potosí, S.L.P., México ${ }^{4}$ Instituto Politécnico Nacional Unidad CIIDIR-Oaxaca, Hornos No. 1003,

Noche Buena, Santa Cruz Xoxocotlán, Oaxaca, México

Received: 10 November 2016

Accepted: 29 December 2016

\begin{abstract}
The soils of a 10-ha agricultural field in the municipality of Guasave, Sinaloa, were characterized through electrical measurements and determination of petrophysical parameters. An electrical profiling survey for $\mathrm{AB} / 2=2 \mathrm{~m}$ and $3 \mathrm{~m}$ was carried out in the study area. The apparent resistivity, soil moisture, and pore water salinity values were recalculated into petrophysical values using the Petrowin software, resulting in fine (clay+silt) content, and porosity and hydraulic conductivity maps. Using the Bouyoucos method, soil texture was determined for 30 soil samples collected in points matched with EP measurement points. The results of textural analysis indicated that the study area is quite complex, with the presence of eight textures of soil, and soil moisture and groundwater salinity variable in twice and five times, respectively. The fines content values obtained from Petrowin software and the Bouyoucos method were compared showing a high correlation $(\mathrm{R}=0.91)$, giving reliability to fast and inexpensive techniques such as electrical profiling for the determination of the soil petrophysical parameters in extensive agricultural land.
\end{abstract}

Keywords: soil parameters, hydraulic conductivity, electrical profiling

*e-mail: hpeinado75@hotmail.com 


\section{Introduction}

There is a wide variety of methods that use both direct and indirect techniques to characterize soils. The direct ones consist of conventional soil boring and subsequent tests made in representative soil samples in order to classify and determine the physical, mechanical, and hydraulic properties. The direct method is the most accurate for soil characterization, but conversely it is time-consuming and expensive. Accurate assessment of soil properties requires close-space drilling, which would be very expensive in many conditions. The direct observations of the soil are mainly destructive techniques. The process of perforation and sampling sometimes facilitates the vertical migration of contaminants, being expensive techniques and its effectiveness depends on factors such as the hardness of the soil and groundwater table depth. On the other hand, the indirect methods are used to determine the physical properties of the soils based on the measurement of other characteristics, such as electrical properties of the soils. Indirect techniques such as electrical resistivity surveys can provide a non-destructive and less expensive method for assessing soil properties [1].

Usually, the planting and harvesting of diverse agricultural products involves extensive land. We need to study and map the soil parameters as rapidly and accurately as possible. Geophysical methods, specifically electrical and electromagnetic methods, are effective, quick, and inexpensive for studies of agriculture fields [2], plus changes in the degree of salinization [3] or moisture [4]. Corwin and Lesch [5] proposed empirical relationships among the petrophysical properties of the soil and the electrical resistivity. Amakor et al. [6] stated an empiric hypothesis to relate soil salinity with resistivity, while Friedman [7] made apparent the influence of soil on electrical conductivity and Heil and Schmidhalter [8] did the same for soil texture and humidity. The electrical resistivity tomography (ERT) method has been efficiently applied on the definition of the plume boundaries in hydrocarbon-contaminated soils [9] and on the estimation of the petrophysical parameters of the soil; resistivity values from ERT and groundwater salinity values obtained in the field allow for the determination of clay content [10], porosity, and CEC sections and maps for the study site [11].

One of the geoelectrical methods widely used in near surface studies is Electrical Profiling (EP). The application of EP is faster than the ERT method; however, EP only provides apparent resistivity values $\left(\rho_{\mathrm{a}}\right)$. Now we consider that the $\rho_{\mathrm{a}}$ value obtained by EP for a study depth of $0.5 \mathrm{~m}$ is similar to the interpreted resistivity $\left(\rho_{1}\right)$ value obtained from ERT for a superficial layer of thickness greater than $0.5 \mathrm{~m}$, at the same point. It is known that, for the left branch of the $\rho_{\mathrm{a}}$ curve versus $\mathrm{AB} / 2$ distance, the asymptotical value tends to $\rho_{1}[12]$; that is, the $\rho_{a}$ value obtained for the lowest value of $A B / 2$ is equal or similar to the true resistivity value interpreted for the first geoelectrical layer (soil). The EP method was used to outline areas with different subsurface resistivities, which indicated different hydrological conditions in soils [13].

According to the aforementioned background, this work is targeted to the application of EP as a fast-forward method, so that $\rho_{\text {a }}$ values, along with the information of soil moisture and pore water salinity, are used to obtain fine content, porosity, and hydraulic conductivity (K)

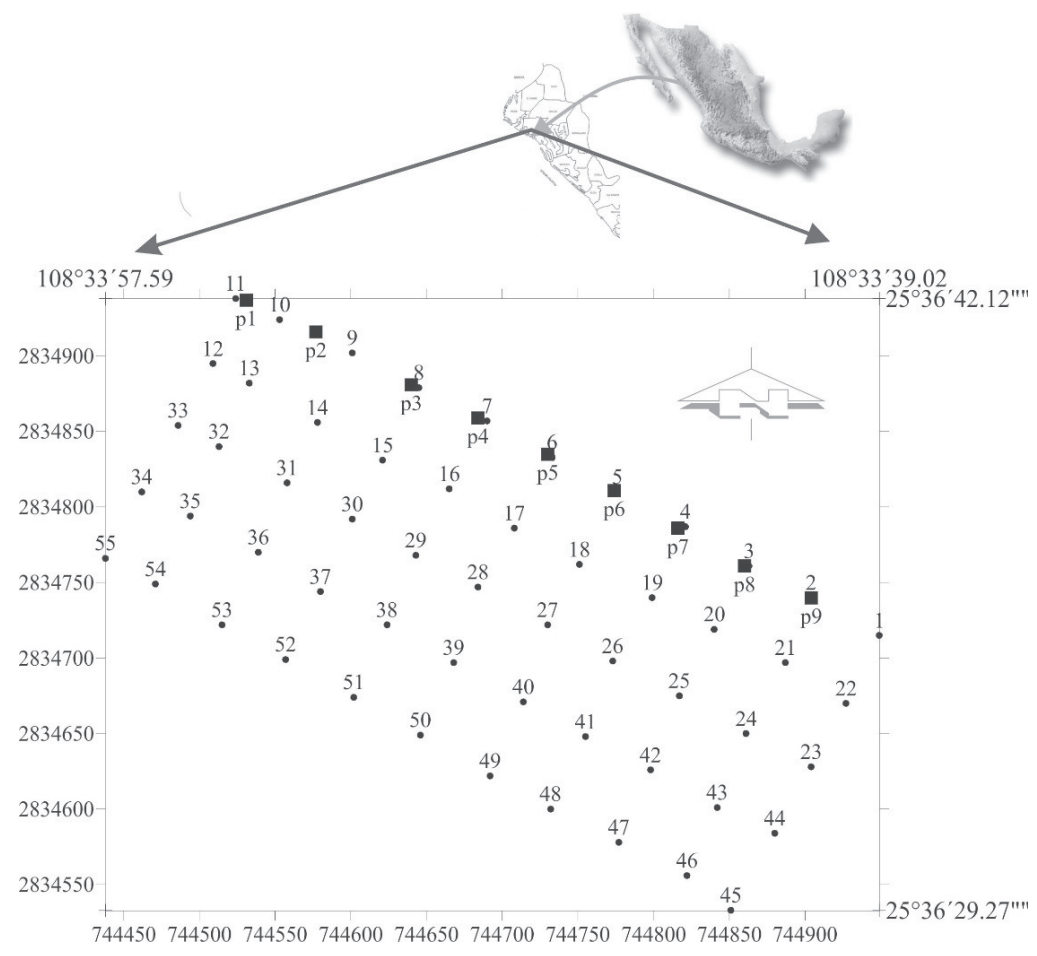

Fig. 1. Location of the study area and distributions of EP measurement points (black dots) and wells (black squares). 
parameters of the soils of an agricultural field. Fine content values will be compared with those determined from textural analysis in order to verify the reliability of the obtained results.

\section{Materials and Methods}

\section{Study Area}

This work was carried out in an agricultural field located $11.7 \mathrm{~km}$ from the city of Guasave in Sinaloa, Mexico $\left(25^{\circ} 36^{\prime} 29.27^{\prime \prime}\right.$ and $25^{\circ} 36^{\prime} 42.12^{\prime \prime}$ north latitude, and $108^{\circ} 33^{\prime} 39.02^{\prime \prime}$ and $108^{\circ} 33^{\prime} 57.59^{\prime \prime}$ west longitude) and comprising an area of 10 hectares (Fig. 1). In this municipality the Vertisol(62.55\%) and Solonchak (21.72\%) soils predominate; Cambisol (3.17\%), kastanozem (2.58\%), Regosol (2.13\%), Phaeozem (1.52\%), Arenosol (1.24\%), Fluvisol (0.92\%), and Leptosol $(0.56 \%)$ soils are also presented [14]. The weather is dry and warm, with an average annual temperature of $25.1^{\circ} \mathrm{C}$, and a minimum and maximum of 2 and $44^{\circ} \mathrm{C}$, respectively. The average annual rainfall on Guasave is $510.5 \mathrm{~mm}$, according to the 1971-87 series [15]. The major rainfall occurs in summer, with a percentage of winter rain between 5.0 and 10.2\% from the annual total. According to information obtained from private wells near the site, the average depth of the groundwater table is $1.2 \mathrm{~m}$.

\section{Determining Soil Moisture and Texture}

The application of direct methods requires the collection of soil samples. For this purpose, a hand-auger was used to collect 30 soil samples of $2 \mathrm{~kg}$ each, at a depth of $30 \mathrm{~cm}$, in points matched with EP measurement points. Each sampling point was geo referenced using a portable GPS. The soil samples are labeled and stored in lowdensity polyethylene bags.

The soil moisture was determined in a lab following the proposed specifications in the lab's soil manual [16] through the following expressions:

$$
H(\%)=\frac{M_{a g}}{M_{s}} x 100
$$

...where $\mathrm{M}=$ mass, $\mathrm{Mag}=$ water mass, $\mathrm{Ms}=$ solids mass (mass of soil dried in oven), and $\mathrm{H}$ is soil moisture.

For determining soil texture, the samples were subjected to a drying homogenate process following the specifications of the NOM-021-RECNAT-2000 [17] using the Bouyoucos method [18].

\section{Determining Groundwater Electrical Conductivity}

Nine wells were drilled in the site to a maximum depth of $1.5 \mathrm{~m}$. The electrical conductivity (EC) of groundwater was determined by the use of a portable conductivimeter model HI 98130 [19], obtaining an EC value in situ for each groundwater sample collected from wells. These values will be used to estimate the pore water salinity values needed in the calculation process of soil petrophysical parameters.

\section{Electrical Profiling (EP) method}

The EP are widely used to study aquifers and properties of the rocks [20-21], to support archaeological survey [22] and geotechnical studies [23-24], and for geological mapping and detection of fractures [25].

The principle of the method consists of performing resistivity measurements through a four-electrode array along a line or profile on the surface. During EP survey, current $(I)$ is injected into the soil and subsoil through a pair of electrodes named A and B. The potential different $(\Delta V)$ is measured by a pair electrodes $M$ and $N$ (Fig. 2). The electrical field is distributed in a soil volume whose size can be estimated from the distance among AMNB electrodes [26]. The geometric factor $K$ can be obtained from the array geometry.

The EP array is moved along the profile, keeping unchanged the mutual distances between electrodes, obtaining a value of $\rho_{\mathrm{a}}$ for each measurement point using equation (2).

The $\rho_{\mathrm{a}}$ value is a bulk average resistivity of all soils and rock influenced by the current. The values of $\rho_{\mathrm{a}}$ obtained in the profile represent the lateral changes of electrical resistivity for a constant study depth:

$$
\rho_{a}=K \frac{\Delta V}{I}
$$

...where $\rho \mathrm{a}$ is the apparent resistivity (Ohms meters), $\mathrm{K}$ is geoelectric constant, $\Delta \mathrm{V}$ is the potential difference measured (volt), and I is the current intensity (amperes).

In this work, an EP survey was conducted. Fifty-five EP measurements were distributed in five parallel profiles using a Schlumberger array for $\mathrm{AB} / 2=2 \mathrm{~m}$ and $3 \mathrm{~m}$ (Fig. 2), guaranteeing the study depths of $0.5 \mathrm{~m}$ and $0.75 \mathrm{~m}$, respectively.

\section{Recalculing Values of Apparent Resistivity, Soil Moisture, and Pore Water Salinity into Fine Content, Porosity, and K Maps}

The $\rho_{\mathrm{a}}$, soil moisture, and pore water salinity values were used to obtain the petrophysical parameters of the

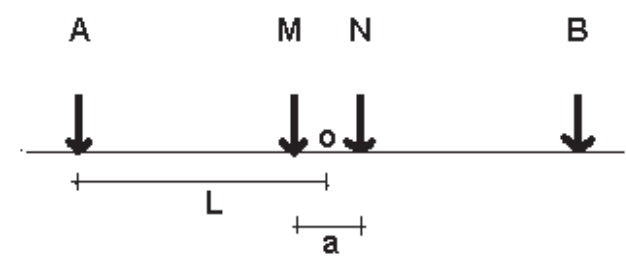

Fig. 2. Schlumberger array used to perform the EP survey. 
soil using Petrowin software developed by A. Ryjov [2728]. The experimental relationship between electrical resistivity as a function of the mineralization of pore water and clay content was first published in Russia by Sharapanov et al. [29]. Then Ryjov [30] published the above-mentioned theoretical relationship. Ryjov and Sudoplatov [28] proposed a model including the components of the poorly consolidated formation and the electrochemical calculation of the resistivity of free water and the water into pores. The solid grains of sand and clay form a nonconductive skeleton. The capillaries are considered as hollow cylinders, having different radium referring to sand and clay. The sand component contains a porous system of cylindrical channels with radii of $10^{-3}-10^{-4} \mathrm{~m}$, which are much larger than the thickness of the electrical double layer. The thickness of the electrical double layer depends on water salinity and increases with decreasing salt concentration. At near-surface conditions, when the salt concentration changes from 0.02 to $2 \mathrm{~g} / 1$, the thickness of the electrical double layer varies in the range of $0.3^{-3} \times 10^{-8} \mathrm{~m}$. The micropores of the clay component are very narrow, and their average radii lie between $10^{-7}$ and $10^{-8} \mathrm{~m}$, which is close to the thickness of the electrical double layer. The capillaries of sand and clay can be connected in series, in parallel, or as a combination of both connections because some part of the clay is usually smeared on pore walls of the sand fraction, and some clay exists in the sand pores as plugs. The total volume of pores in sand and clay is expressed through porosity values on a separated form for sand and clay. A more detailed explanation about characteristics of the theoretical model can be found in Shevnin et al. [10].

An example of the results obtained from a theoretical model is presented in Fig. 3. Different curves show the behavior of soil resistivity for different pore water salinities according to the clay content and soil porosity. The model considers soil moisture $100 \%$ and CEC of clay $3 \mathrm{~g} / \mathrm{L}$. The values on curves indicate clay content from 0 (sand) up to 100 (pure clay) and soil porosity in percentage. The dashed line indicates water resistivity. A process of fitting between the electrical resistivity curve calculated from the theoretical model (Fig. 3) previously described and the experimental curve obtained from electrical measurements performed in soil sample for different porewater salinity, shifting different petrophysical parameters of the theoretical model such as: clay CEC, radium of the capillaries of clay, and porosity of the clay and the sand. In the case of silt, the behavior of the electrical resistivity values versus pore water salinity is similar to clay with low CEC values. For this reason, we will hereafter refer fine content to the sum of the clay and silt contents. The final result is the determination of fine content (clay+silt) and porosity parameters. $\mathrm{K}$ value is a function of fine content according to the relationship proposed by Shevnin et al. [9] and Delgado et al. [31].

If we use the interpreted apparent resistivity values obtained from the EP survey and salinity values calculated in groundwater samples, instead of a curve of resistivity versus salinity for a soil sample from

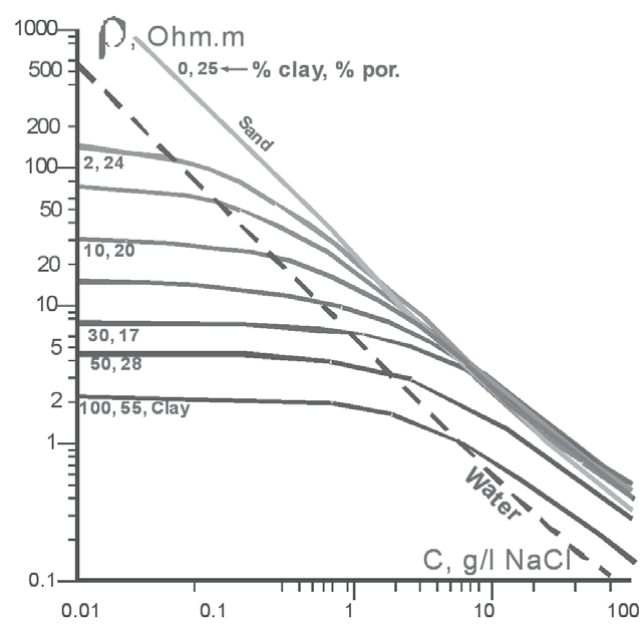

Fig. 3. Theoretical dependence of the resistivity of a sandy-clay mixture on groundwater salinity.

electrical measurements made in a laboratory, it is then possible to determine petrophysical parameter maps for fine content, porosity, and $\mathrm{K}$. This procedure uses the same petrophysical modeling algorithm and can convert resistivity maps into petrophysical maps [11].

So, using the apparent soil resistivity values obtained from the EP survey, soil moisture, and groundwater salinity values, it is possible to determine the fine content, porosity, and $\mathrm{K}$ maps of the study site.

\section{Results and Discussion}

\section{Soil Moisture and Textural Analysis}

The 30 soil samples were subjected to a dry and homogenate process to determine the percentage of

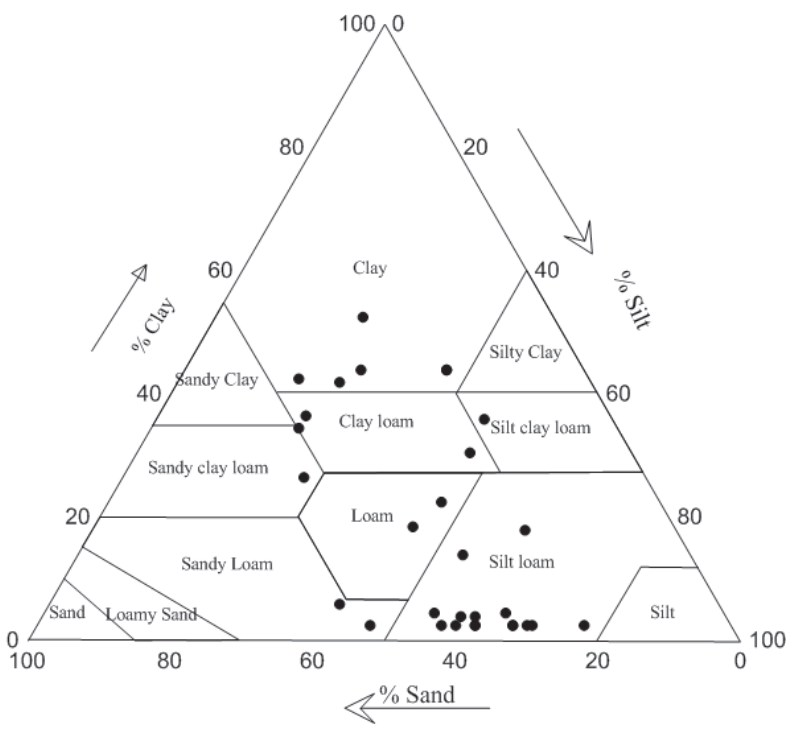

Fig. 4. Soil textures present in the study area according to the results obtained using the Bouyoucos method. 
Table 1. Soil texture and moisture obtained for 30 soil samples collected in the study area.

\begin{tabular}{|c|c|c|c|c|c|c|}
\hline \multirow{2}{*}{ Soil Sample* } & \multicolumn{2}{|c|}{ Coordinates } & \multirow{2}{*}{$\begin{array}{c}\% \\
\text { Sand }\end{array}$} & \multirow{2}{*}{$\begin{array}{c}\% \\
\text { Silt }\end{array}$} & \multirow{2}{*}{$\begin{array}{c}\% \\
\text { Clay }\end{array}$} & \multirow{2}{*}{$\begin{array}{c}\% \\
\text { Moisture }\end{array}$} \\
\hline & $\mathrm{X}$ & $\mathrm{Y}$ & & & & \\
\hline 1 & 744949 & 2834715 & 18 & 46 & 36 & 23.2 \\
\hline 3 & 744863 & 2834761 & 43 & 21 & 37 & 14.2 \\
\hline 5 & 744776 & 2834810 & 45 & 21 & 35 & 17.5 \\
\hline 7 & 744690 & 2834857 & 31 & 67 & 3 & 20.2 \\
\hline 9 & 744601 & 2834902 & 31 & 65 & 5 & 23.9 \\
\hline 11 & 744524 & 2834938 & 21 & 77 & 3 & 26.3 \\
\hline 12 & 744509 & 2834895 & 21 & 61 & 18 & 28.8 \\
\hline 14 & 744578 & 2834856 & 31 & 67 & 3 & 21.5 \\
\hline 16 & 744665 & 2834812 & 32 & 54 & 14 & 18.9 \\
\hline 18 & 744751 & 2834762 & 48 & 25 & 27 & 18.1 \\
\hline 20 & 744840 & 2834719 & 37 & 45 & 19 & 21.7 \\
\hline 22 & 744927 & 2834670 & 27 & 21 & 53 & 21.7 \\
\hline 23 & 744904 & 2834628 & 36 & 61 & 3 & 24.1 \\
\hline 25 & 744817 & 2834675 & 39 & 59 & 3 & 26.8 \\
\hline 27 & 744730 & 2834722 & 53 & 41 & 6 & 16.1 \\
\hline 29 & 744643 & 2834768 & 41 & 55 & 5 & 19.7 \\
\hline 31 & 744558 & 2834816 & 31 & 47 & 23 & 19.2 \\
\hline 33 & 744486 & 2834854 & 28 & 69 & 3 & 23.9 \\
\hline 34 & 744462 & 2834810 & 36 & 61 & 3 & 18.3 \\
\hline 36 & 744539 & 2834770 & 23 & 47 & 31 & 21.8 \\
\hline 38 & 744624 & 2834722 & 35 & 23 & 42 & 18.7 \\
\hline 40 & 744714 & 2834671 & 41 & 17 & 43 & 21.2 \\
\hline 42 & 744798 & 2834626 & 31 & 25 & 44 & 23.7 \\
\hline 44 & 744880 & 2834584 & 29 & 69 & 3 & 21.0 \\
\hline 45 & 744851 & 2834533 & 19 & 37 & 44 & 23.6 \\
\hline 47 & 744777 & 2834578 & 19 & 37 & 44 & 22.0 \\
\hline 49 & 744692 & 2834622 & 51 & 47 & 3 & 19.5 \\
\hline 51 & 744602 & 2834674 & 37 & 59 & 4 & 18.7 \\
\hline 53 & 744515 & 2834722 & 41 & 57 & 3 & 17.7 \\
\hline 55 & 744438 & 2834766 & 35 & 61 & 4 & 21.3 \\
\hline
\end{tabular}

* Sample number is assigned according to EP measurement point (see Fig. 1).

moisture in each soil sample. After that, textural analysis by the Bouyoucos method was performed and the results are shown in Table 1 with its respective percentages of moisture variables between $14.2 \%$ and $28.8 \%$. Soil moisture content is influenced by site, seasonal effect represented by date of sampling, and soil depth [32] and soil degradation [33].

The percentages of sand, silt, and clay were plotted inside the texture triangle to obtain the classification of the soil, where a wide variety of soil texture can be observed: clay, silty clay, clay loam, loam, sandy loam, silt loam, sandy clay loam, and silt clay loam (Fig. 4). The low content of clay in sandy soils usually limits humus accumulation, nutrients, and water availability [34].

The clay content is higher in the SE and central portions of the study area, decreasing significantly toward the NW end of the site. The silt content is greater toward the $\mathrm{N}$ and $\mathrm{SE}$ ends of the site, decreasing in the central part, while the 


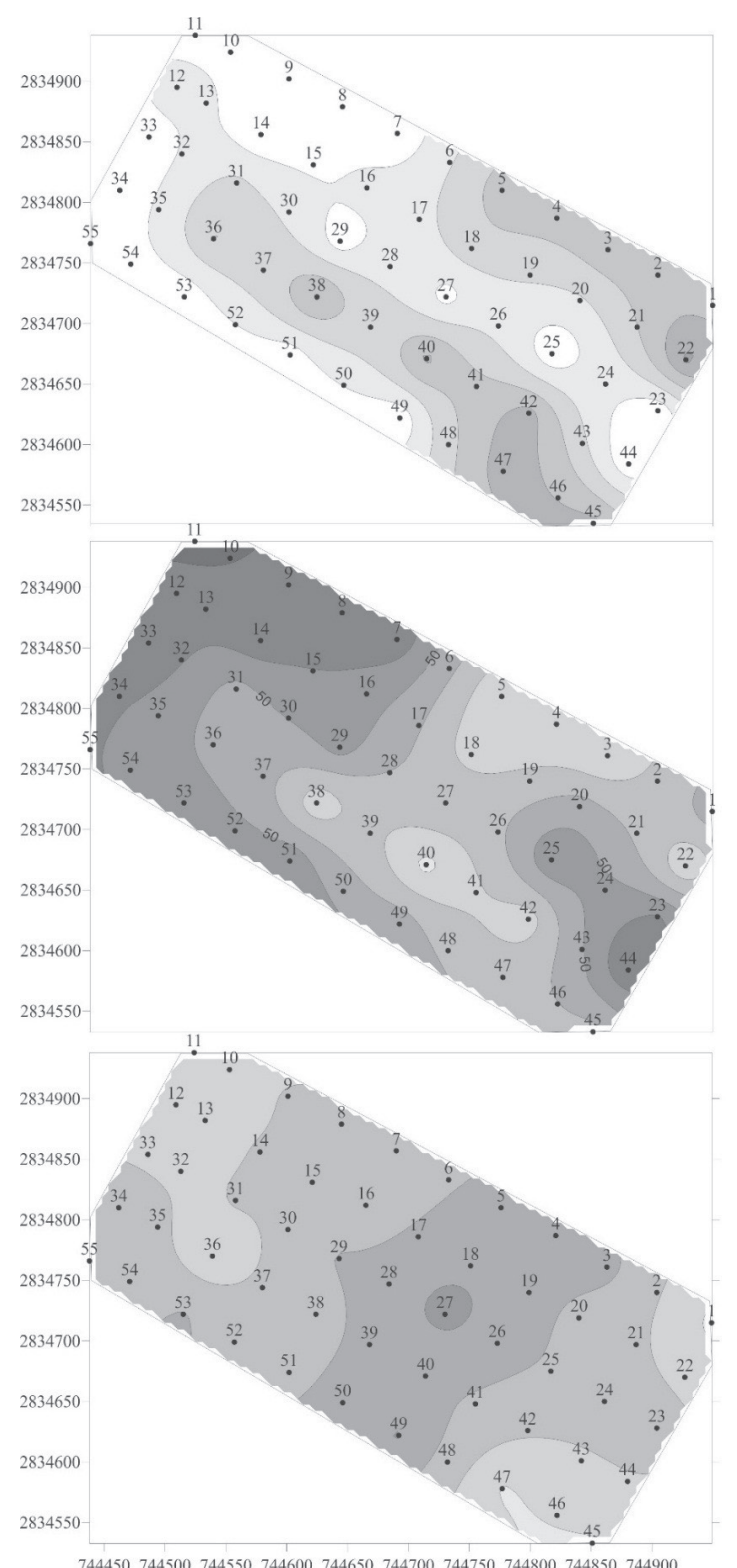

Fig. 5. Soil texture maps obtained using the Bouyocus method.

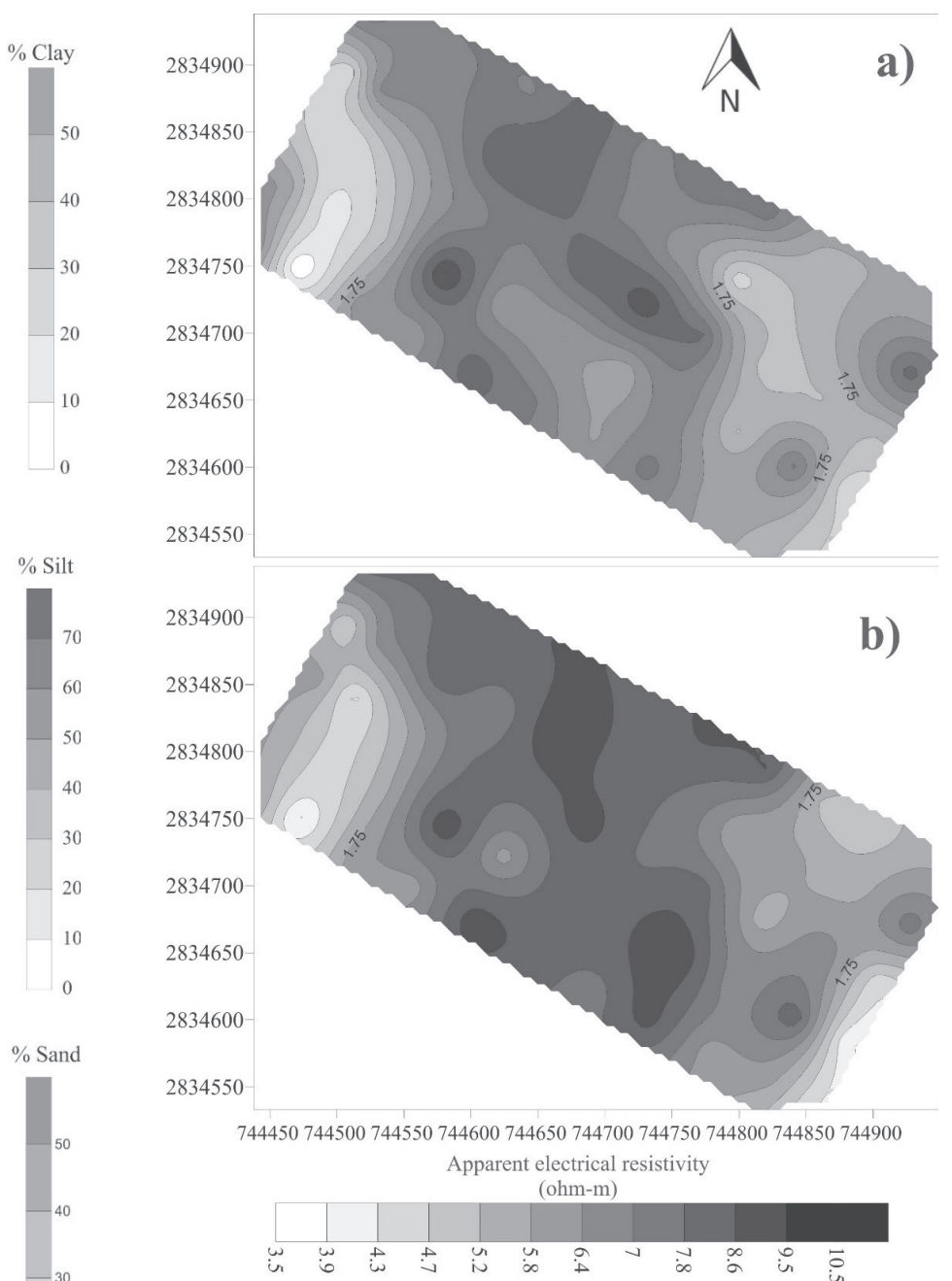

Fig. 6. Apparent electrical resistivity maps from the application of the $\mathrm{EP}$ method for a) $\mathrm{AB} / 2=2 \mathrm{~m}$ and $\mathrm{b}$ ) $\mathrm{AB} / 2=3 \mathrm{~m}$.

sand content is inversely distributed to the silt, with higher concentrations in the central part of the study area (Fig. 5). Several authors have measured and assessed based on the triangular soil mixture diagram in order to establish the

Table 2. Groundwater electrical conductivity (EC) and salinity values determined in nine wells.

\begin{tabular}{|c|c|c|c|c|c|}
\hline \multirow{2}{*}{ Well } & \multicolumn{2}{|c|}{ Coordinates } & \multirow{2}{*}{$\begin{array}{c}\mathrm{EC} \\
(\mathrm{mS} / \mathrm{cm})\end{array}$} & \multirow{2}{*}{$\begin{array}{l}\text { Salinity } \\
(\mathrm{g} / \mathrm{l})\end{array}$} & \multirow{2}{*}{$\begin{array}{l}\text { Water Table Depth } \\
\qquad(\mathrm{m})\end{array}$} \\
\hline & $X$ & $\mathrm{Y}$ & & & \\
\hline 1 & 744531 & 2834937 & 0.58 & 0.35 & 1.2 \\
\hline 2 & 744577 & 2834916 & 0.89 & 0.53 & 1.2 \\
\hline 3 & 744640 & 2834881 & 0.83 & 0.50 & 1.3 \\
\hline 4 & 744684 & 2834859 & 0.82 & 0.49 & 1.4 \\
\hline 5 & 744730 & 2834835 & 0.77 & 0.46 & 1.3 \\
\hline 6 & 744774 & 2834811 & 0.98 & 0.59 & 1.7 \\
\hline 7 & 744816 & 2834786 & 2.67 & 1.60 & 1.2 \\
\hline 8 & 744860 & 2834761 & 2.85 & 1.71 & 0.7 \\
\hline 9 & 744904 & 2834740 & 2.99 & 1.79 & 1.8 \\
\hline
\end{tabular}


Table 3. Apparent resistivity values of the $55 \mathrm{EP}$ points for $\mathrm{AB} / 2=2 \mathrm{~m}$ and $3 \mathrm{~m}$.

\begin{tabular}{|c|c|c|c|c|}
\hline \multirow{2}{*}{$\begin{array}{c}\text { EP } \\
\text { point }\end{array}$} & \multicolumn{2}{|c|}{ Coordinates } & \multirow{2}{*}{$\frac{\rho \mathrm{a}(\mathrm{Ohm} \cdot \mathrm{m})}{\mathrm{AB} / 2=2 \mathrm{~m}}$} & \multirow{2}{*}{$\frac{\rho \mathrm{a}(\mathrm{Ohm} \cdot \mathrm{m})}{\mathrm{AB} / 2=3 \mathrm{~m}}$} \\
\hline & $\mathrm{X}$ & Y & & \\
\hline 1 & 744949 & 2834715 & 5.7 & 5.7 \\
\hline 2 & 744904 & 2834740 & 5.8 & 5.0 \\
\hline 3 & 744863 & 2834761 & 5.6 & 5.1 \\
\hline 4 & 744821 & 2834787 & 8.1 & 8.6 \\
\hline 5 & 744776 & 2834810 & 8.4 & 8.7 \\
\hline 6 & 744733 & 2834833 & 7.4 & 8.3 \\
\hline 7 & 744690 & 2834857 & 9.1 & 8.6 \\
\hline 8 & 744645 & 2834879 & 7.7 & 8.5 \\
\hline 9 & 744601 & 2834902 & 7.8 & 7.8 \\
\hline 10 & 744553 & 2834924 & 7.3 & 7.7 \\
\hline 11 & 744524 & 2834938 & 8.3 & 8.2 \\
\hline 12 & 744509 & 2834895 & 4.3 & 4.8 \\
\hline 13 & 744533 & 2834882 & 7.3 & 6.7 \\
\hline 14 & 744578 & 2834856 & 7.2 & 8.5 \\
\hline 15 & 744621 & 2834831 & 9.5 & 7.2 \\
\hline 16 & 744665 & 2834812 & 9.2 & 9.5 \\
\hline 17 & 744708 & 2834786 & 7.8 & 8.1 \\
\hline 18 & 744751 & 2834762 & 6.7 & 7.7 \\
\hline 19 & 744799 & 2834740 & 4.4 & 5.7 \\
\hline 20 & 744840 & 2834719 & 5.2 & 6.0 \\
\hline 21 & 744887 & 2834697 & 6.2 & 5.5 \\
\hline 22 & 744927 & 2834670 & 9.1 & 7.5 \\
\hline 23 & 744904 & 2834628 & 5.3 & 4.4 \\
\hline 24 & 744861 & 2834650 & 5.2 & 6.9 \\
\hline 25 & 744817 & 2834675 & 5.0 & 5.4 \\
\hline 26 & 744773 & 2834698 & 8.8 & 8.2 \\
\hline 27 & 744730 & 2834722 & 10.4 & 7.5 \\
\hline
\end{tabular}

erosion level [35], irrigation capability [36], physical and chemical features of soils [37], and hydraulic properties [38], among others.

\section{Pore-Water Salinity}

Table 2 shows the electrical conductivity (EC) values determined for groundwater samples collected from nine wells. The behavior of groundwater conductivity is variable with minimum and maximum values of $0.58 \mathrm{mS} / \mathrm{cm}$ and $2.99 \mathrm{mS} / \mathrm{cm}$, respectively. According to Vargas [39], less than $1.254 \mathrm{mS} / \mathrm{cm}$ conductivities correspond to freshwater, so the study area includes both fresh and brackish water.

\begin{tabular}{|l|l|l|l|l|}
\hline 28 & 744684 & 2834747 & 9.3 & 9.1 \\
\hline 29 & 744643 & 2834768 & 7.8 & 8.0 \\
\hline 30 & 744601 & 2834792 & 7.3 & 7.8 \\
\hline 31 & 744558 & 2834816 & 5.8 & 5.9 \\
\hline 32 & 744513 & 2834840 & 4.3 & 4.1 \\
\hline 33 & 744486 & 2834854 & 4.5 & 6.0 \\
\hline 34 & 744462 & 2834810 & 6.3 & 5.5 \\
\hline 35 & 744494 & 2834794 & 4.1 & 4.5 \\
\hline 36 & 744539 & 2834770 & 5.3 & 5.8 \\
\hline 37 & 744580 & 2834744 & 10.9 & 9.5 \\
\hline 38 & 744624 & 2834722 & 6.3 & 6.0 \\
\hline 39 & 744668 & 2834697 & 6.3 & 8.3 \\
\hline 40 & 744714 & 2834671 & 5.9 & 8.4 \\
\hline 41 & 744755 & 2834648 & 7.6 & 9.5 \\
\hline 42 & 744798 & 2834626 & 5.1 & 6.5 \\
\hline 43 & 744842 & 2834601 & 8.0 & 8.4 \\
\hline 44 & 744880 & 2834584 & 4.3 & 3.9 \\
\hline 45 & 744851 & 2834533 & 4.7 & 4.3 \\
\hline 46 & 744822 & 2834556 & 5.7 & 6.0 \\
\hline 47 & 744777 & 2834578 & 6.1 & 6.1 \\
\hline 48 & 744732 & 2834600 & 8.2 & 9.0 \\
\hline 49 & 744692 & 2834622 & 6.3 & 7.3 \\
\hline 50 & 744646 & 2834649 & 8.0 & 8.3 \\
\hline 51 & 744602 & 2834674 & 9.2 & 9.3 \\
\hline 52 & 744557 & 2834699 & 6.5 & 6.0 \\
\hline 53 & 744515 & 2834722 & 6.7 & 6.3 \\
\hline 54 & 744471 & 2834749 & 3.4 & 3.7 \\
\hline 55 & 744438 & 2834766 & 7.3 & 6.1 \\
\hline
\end{tabular}

Similarly, groundwater salinity is variable with maximum and minimum values of $0.35 \mathrm{~g} / 1$ and $1.79 \mathrm{~g} / \mathrm{l}$, respectively. EC values and, consequently, groundwater salinity increase five times in the direction SE-NW. The salinity values will be considered as water pore salinity during the calculation process of the petrophysical parameters.

\section{Analysis of the Apparent Resistivity Values Obtained from EP Survey}

We considered the site as a complex study area due to the high variability of soil moisture and texture, and porewater salinity, which should be reflected in the distribution 
Table 4. Statistical analysis of the resistivity apparent values for $\mathrm{AB} / 2=2 \mathrm{~m}$ and $3 \mathrm{~m}$.

\begin{tabular}{|c|c|c|c|c|c|c|c|}
\hline \multicolumn{8}{|c|}{ T-test for independent samples } \\
\hline & Mean & t-value & df & $\mathrm{p}$ & Std. Dev. & F-ratio Variances & $\mathrm{p}$ Variances \\
\hline Group $1 \quad\left(\rho_{\mathrm{a}}\right.$ for $\left.\mathrm{AB}=2 \mathrm{~m}\right)$ & 6.93 & \multirow{2}{*}{0.42} & \multirow{2}{*}{108} & \multirow{2}{*}{0.68} & 1.6324 & \multirow{2}{*}{1.14} & \multirow{2}{*}{0.63} \\
\hline Group $2\left(\rho_{\mathrm{a}}\right.$ for $\left.\mathrm{AB}=3 \mathrm{~m}\right)$ & 6.80 & & & & 1.7435 & & \\
\hline
\end{tabular}

of $\rho$ values. Fig. 6 shows the apparent resistivity maps for a) $\mathrm{AB} / 2=2 \mathrm{~m}$ and b) $\mathrm{AB} / 2=3 \mathrm{~m}$, which are presented showing great similarity. A central resistive zone and decrease in $\rho_{\mathrm{a}}$ values toward NW and SE ends of the site are observed in both maps.

The similarity between the two maps of Fig. 6 is backed up on the analysis of $\rho_{\mathrm{a}}$ values for $\mathrm{AB} / 2=2 \mathrm{~m}$ and $3 \mathrm{~m}$, presented in Tables 3-4. The mean $\rho_{\mathrm{a}}$ value for the $\mathrm{AB} / 2=2 \mathrm{~m}$ is $6.8 \mathrm{Ohm} . \mathrm{m}$, with maximum, minimum, and standard deviation values of $10.9,3.4$, and $1.74 \mathrm{Ohm} . \mathrm{m}$, respectively. For $\mathrm{AB} / 2=3 \mathrm{~m}$ the mean value is 6.9 Ohm.m with a maximum of $9.5 \mathrm{Ohm} . \mathrm{m}$, minimum of $3.7 \mathrm{Ohm} . \mathrm{m}$, and standard deviation of $1.63 \mathrm{Ohm} . \mathrm{m}$. Table 4 shows the mean resistivity and standard deviations values. According to the T-test for independent samples, no significant difference between $A B / 2$ values was observed ( $p>0.05$ ), so we decided to use only the apparent resistivity values for $\mathrm{AB} / 2=2 \mathrm{~m}$,

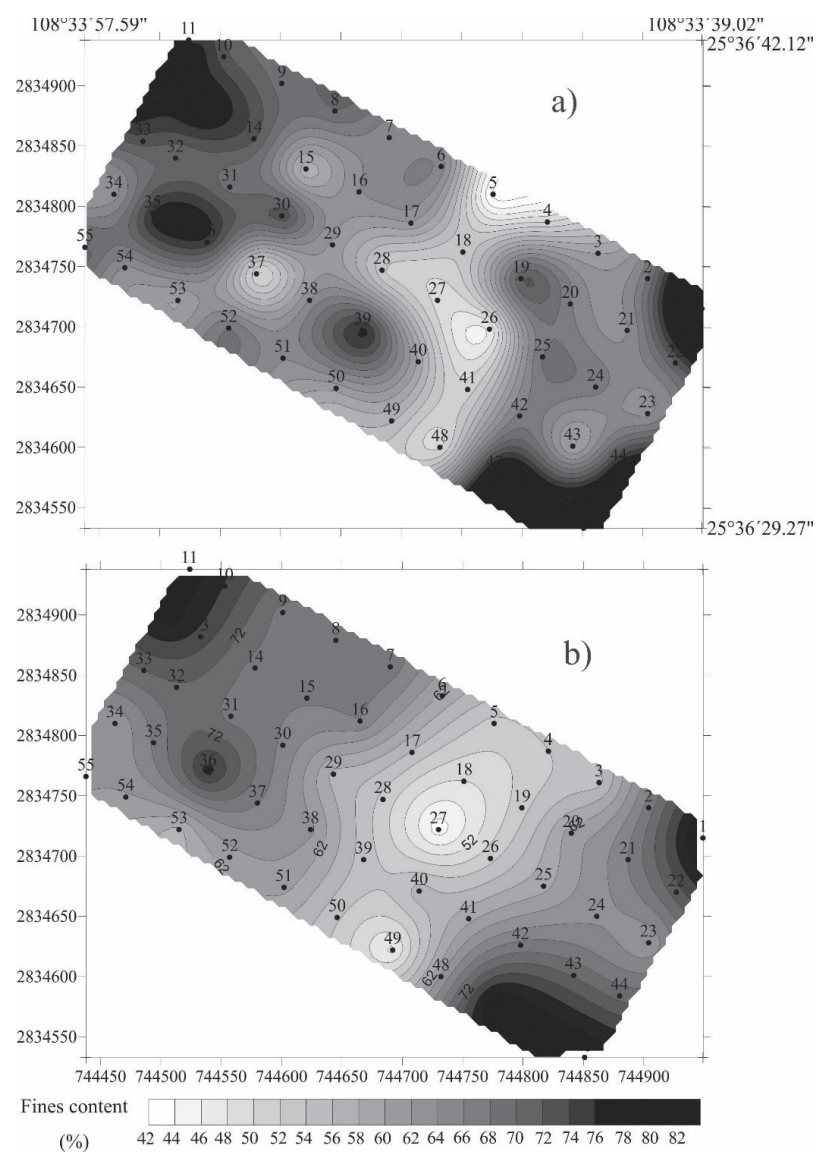

Fig. 7. Comparison between the distributions of fine content obtained using a) Petrowin software and b) Bouyoucos method. i.e., a study depth of $0.5 \mathrm{~m}$, ensuring that the value of $\rho$ is not affected by soil substrate. Measurements of soil $\rho \mathrm{a}$ are useful in near-surface studies [40], investigating soil contamination [41], and planning and analyzing agricultural experiments [42].

\section{Fines Content, Porosity, and K Maps}

The $\rho_{\mathrm{a}}$ values, along with information of soil moisture and salinity of pore water, were processed using Petrowin software to obtain fine content, porosity, and $\mathrm{K}$ values. Figure 7 shows similar maps of fines content determined from Petrowin software (Fig. 7a) and the Bouyoucos method (Fig. 7b) are presented. Fines content values from the Bouyoucos method were determined as the sum of clay and silt content values (Table 1). The similarity between both fine content maps (Fig. 7) is verified in the linear correlation graph presented in Fig. 8, showing a value of high positive correlation, $\mathrm{R}=0.91$, and variance of 0.82 , giving reliability to the results obtained from petrophysical modeling.

The petrophysical parameters constitute basic data for diverse investigations or practice works of economic interest [43-44]. The knowledge of these parameters allows for the optimal use of soils; for example: hydraulic conductivity (Fig. 9) and porosity (Fig. 10) maps help us understand the capacity infiltration and storage of the soil; the capacity of soil salinization and contamination vulnerability are related to the fine content, which is useful for making decisions regarding management, protection,

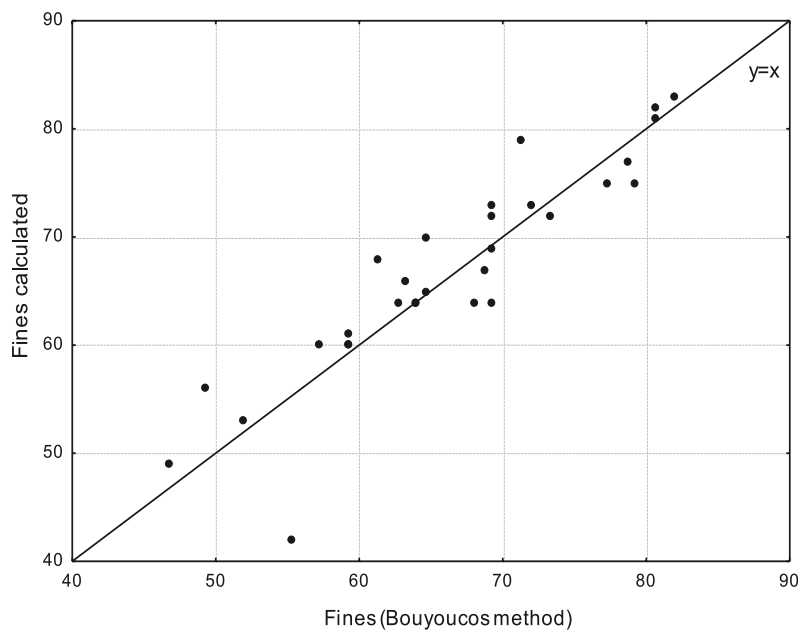

Fig. 8. Linear correlation graph between fine contents values determined by using the Bouyoucos and EP methods. 


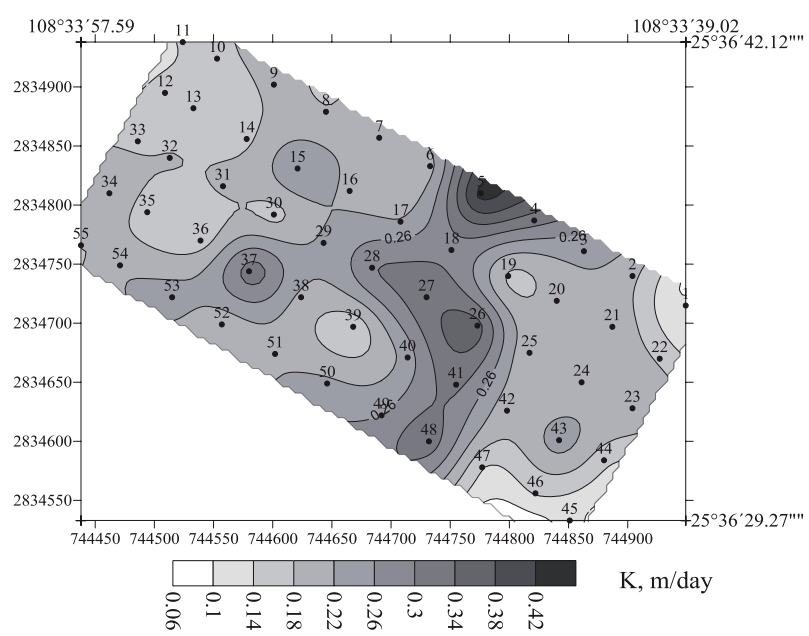

Fig. 9. Distribution of the hydraulic conductivity values obtained using Petrowin software.

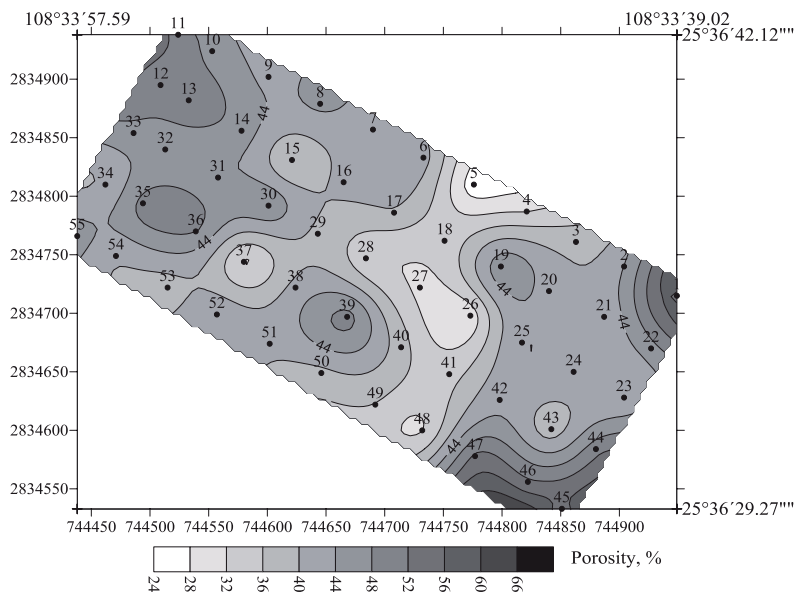

Fig. 10. Distribution of the porosity values obtained using Petrowin software.

and prediction of contaminant migration. So knowledge of petrophysical parameters is needed to advance the knowledge of a geological environment.

Fig. 10 shows the behavior of porosity, with values between $24 \%$ and $66 \%$. This soil property is tightly related to efficiency of the agricultural exploitation. According to [45], the porosity fluctuates as a function type of soil and soil use, for example soils with natural vegetation have higher porosity due to the intense biological activity and the lack of human interference, having better physical properties than soils used for pasture or agricultural activities.

\section{Conclusions}

The characterization of soils in extensive agricultural fields requires the application of fast-forward and inexpensive methods. The application of direct methods is expensive, slow, and destructive, while indirect techniques such as electrical methods offer low-cost and nondestructive tools for soil studies. In an agricultural field of 10 ha in the municipality of Guasave, Sinaloa, we applied EP as a fast-forward indirect method so that $\rho_{\text {a }}$ values, along with the information of soil moisture and groundwater salinity, were processed using Petrowin software to obtain petrophysical parameters of the soils. The results obtained using Petrowin are presented in maps of fines content, porosity, and $\mathrm{K}$ - all useful in the analysis of soil characteristics such as predicting contaminant migration, capacity infiltration, storage of the soil, and soil fertility.

Using the Bouyoucos method, soil texture was determined for 30 soil samples collected in points matched with EP measurement points. The results of textural analysis showed the presence of a wide variety of soil texture, moisture, and groundwater salinity. So the agricultural field is a complex site, optimal for testing the efficiency of the EP method for determining soil characteristics using Petrowin.

The fines content values obtained from Petrowin and the Bouyoucos method were compared, showing a good correlation $(\mathrm{R}=0.91)$ and giving reliability to the EP method as a fast and inexpensive technique for determining the petrophysical parameters of soil in extensive agricultural land. This result will be the basis for the future application of EM profiling (e.g., EM38, study depth of $0.75 \mathrm{~m}$ ) as a faster technique (although more sensitive to EM noise).

\section{Acknowledgements}

Our gratitude to the general direction of research and post graduate of the Autonomous University of Sinaloa for supporting our project and generating suitable conditions to fulfill the present work.

\section{References}

1. KAZMI D., QASIM S., SIDDIQUI F.I., AZHAR S.B. Exploring the Relationship between Moisture Content and Electrical Resistivity for Sandy and Silty Soils. International Journal of Engineering Science Invention, 5 (7), 42, 2016.

2. SUDDUTH K.A., DRUMMOND S.T., KITCHEN N.R. Measuring and interpreting soil electrical conductivity for precision agriculture. Second International Geospatial Information in Agriculture and Forestry Conference, Lake Buena Vista, Florida, 2000.

3. WILLIAMS B.G., BAKER G.C. An electromagnetic induction technique for reconnaissance surveys of soil salinity hazards. Australian Journal of Soil Research, 20, 107, 1982.

4. MCKENZIE R.C., CHOMISTEK W., CLARK N.F. Conversion of electromagnetic induction readings to saturated paste extract values in soils for different temperature, texture, and moisture conditions. Canadian Journal of Soil Science, 69, 25, 1989. 
5. CORWIN D.L., LESCH S.M. Characterizing soil spatial variability with apparent soil electrical conductivity: I. Survey protocols. Computers and electronics in agriculture, 46 (1), $103,2005$.

6. AMAKOR X.N., JACOBSON A.R., CARDON G.E., HAWKS A.A. comparison of salinity measurement methods based on soil saturated pastes. Geoderma, 219, 32, 2014.

7. FRIEDMAN S.P. Soil properties influencing apparent electrical conductivity: a review. Comput. Electron. Agric. 46, 45, 2005.

8. HEIL K., SCHMIDHALTER U. Characterization of soil texture variability using the apparent soil electrical conductivity at a highly variable site. Computers \& Geosciences, 39, 98, 2012.

9. SHEVNIN V., DELGADO O., MOUSATOV A., RYJOV A. Estimation of hydraulic conductivity on clay content in soil determined from resistivity data. Geofísica Internacional, 45 (3), 195, 2006.

10. SHEVNIN V., MOUSATOV A., RYJOV A.A., DELGADORODRÍGUEZ O. Estimation of clay content in soil based on resistivity modeling and laboratory measurements. Geophysical Prospecting, 55, 265, 2007.

11. DELGADO-RODRÍGUEZ O., LADRÓN DE GUEVARATORRES M., SHEVNIN V., RYJOV A. Estimation of soil petrophysical parameters based on electrical resistivity values obtained from $\mathrm{lab}$ and in-field measurements. Geofísica Internacional, 51 (1), 5, 2012.

12. KELLER G., FRISCHKNECHT F. Electrical Methods in Geophysical Prospecting, 517, 1966.

13. POZDNYAKOVA L., POZDNYAKOV A., ZHANG R. Application of geophysical methods to evaluate hydrology and soil properties in urban areas. Urban Water, 3 (3), 205, 2001.

14. INEGI, Prontuario municipal geographic information of the United Mexican States, Guasave, Sinaloa, key Geostatistics 25011, México, 1, 2009.

15. PEINADO H.J., GREEN C.R., HERRERA J., ESCOLERO O.A., DELGADO O., BELMONTE S.I., LADRON DE GUEVARA M. Quality and suitability of agricultural and domestic water aquifer of Sinaloa's River, coastal portion use. Hidrobiológica, 21, 63, 2011.

16. FORSYTHE W. Soil physics: Laboratory Manual. IICA. Saint Joseph, Costa Rica, 1985.

17. SEMARNAT. NOM-021-RECNAT-2000: The specifications for fertility, salinity and soil classification. Studies, sampling and analysis. Official Journal of the Federation 85, 2000.

18. BOUYOUCOS G. J. Hydrometer method improved for making particle size analyses of soils. Agronomy Journal, 54 (5), 464, 1962.

19. HANNA INSTRUMENTS. HI 98129 and HI 98130. Instruction Manual, http://hannainst.com/hi98129-ph-ectds-tester.html\#downloads, 2005.

20. AUGE M. Geoelectric Methods for Groundwater Exploration. University of Buenos Aires, Buenos Aires, 2008.

21. UCHA E.L.D., MEJIAS J.M., BOSCH A.P. Study of aquifers in igneous and metamorphic rocks through surveys and electrical profiling: application to the Valley of $\mathrm{La}$ Granjuela (Córdoba). I Spanish Congress of Geology, Association of Geologists of Madrid, 261, 1984.

22. PERDOMO S. Electrical tomography in support of archaeological research (Doctoral dissertation, Faculty of Astronomy and Geophysics), 2013.

23. ADEBISI N.O., ARIYO S.O., SOTIKARE P.B. Electrical resistivity and geotechnical assessment of subgrade soils in southwestern part of Nigeria. Journal of African Earth Sciences, 119, 256, 2016.

24. CARDENAS L.M. Study of grounding systems of buildings of: Bellas Artes, Multidisciplinary Center, Industrial, Administrative, Welfare University and Center for Innovation and Technological Development of Technological University of Pereira, 2015.

25. JORDÁ L. Geophysical techniques reconnaissance ground: ground penetrating radar and electrical tomography. Practical cases. Basement and Urban Work, 34, 2005.

26. JAKOSKY J.J. Exploration Geophysics. Times-Mirror Press, 1195, 1950.

27. RYJOV A., SHEVNIN V. Theoretical calculation of rocks electrical resistivity and some examples of algorithm's application. In: Proceedings of the Symposium on the Application of Geophysics to Engineering and Environmental Problems, 2002.

28. RYJOV A.A., SUDOPLATOV A.D. The calculation of specific electrical conductivity for sandy-clayed rocks and the usage of functional cross-plots for the decision of hydrogeological problems. In: «Scientific and technical achievements and advanced experience in the field of geology and mineral deposits research. Moscow, 27, 1990.

29. SHARAPANOV N.N., CHERNIAK G.J., BARON V.A. Geophysical methods at hydrogeological survey for land improvement. Moscow, Nedra, 1974.

30. RYJOV A. The main IP peculiarities of rocks. In: Application of IP method for mineral deposits> research. Moscow, 5, 1987.

31. DELGADO O., PEINADO H.J., GREEN C.R., HERRERA J., SHEVNIN V. Determination of hydraulic conductivity and fines content in soils near an unlined irrigation canal in Guasave, Sinaloa. J. Soil Sci. Plant Nutr., 11 (3), 13, 2011.

32. CEJPEK J., KURÁZ V., FROUZ J. Hydrological properties of soils in reclaimed and unreclaimed sites after brown-coal mining. Polish Journal of Environmental Studies, 22 (3), 645, 2013.

33. LI H., ZHANG F., MAO S., ZHU J., YANG Y., HE H., LI Y. Effects of Grazing Exclusion on Soil Properties in Maqin Alpine Meadow, Tibetan Plateau, China. Polish Journal of Environmental Studies, 25 (4), 1583, 2016.

34. CZABAN J., SIEBIELEC G. Effects of bentonite on sandy soil chemistry in a long-term plot experiment (II); effect on $\mathrm{pH}, \mathrm{CEC}$, and macro-and micronutrients. Polish Journal of Environmental Studies, 22 (6), 1669, 2013.

35. VAEZI A.R., HASANZADEH H., CERDÀ A. Developing an erodibility triangle for soil textures in semi-arid regions, NW Iran. Catena, 142, 221, 2016.

36. UMWENI A.S., OGUNKUNLE A.O. Irrigation Capability Evaluation of Illushi Floodplain, Edo State, Nigeria. International Soil and Water Conservation Research, 2 (2), 79, 2014.

37. MAZUREK R., KOWALSKA J., GĄSIOREK M., SETLAK M. Micromorphological and physico-chemical analyses of cultural layers in the urban soil of a medieval city - A case study from Krakow, Poland. Catena, 141, 73, 2016.

38. BARDHAN G., RUSSO D., GOLDSTEIN D., LEVY G.J. Changes in the hydraulic properties of a clay soil under longterm irrigation with treated wastewater. Geoderma, 264, 1, 2016.

39. VARGAS J.R. Manejo integrado de aguas subterráneas: un reto para el futuro. Euned, 2002.

40. FALEIRO E., ASENSIO G., MORENO J. Improved measurements of the apparent resistivity for small depths in Vertical Electrical Soundings. Journal of Applied Geophysics, 131, 117, 2016. 
41. PIERWOŁA J. Investigation of soil contamination using resistivity and induced polarization methods. Polish Journal of Environmental Studies, 22 (6), 1781, 2013.

42. RUDOLPH S., WONGLEECHAROEN C., LARK R.M., MARCHANT B.P., GARRÉ S., HERBST M., WEIHERMÜLLER L. Soil apparent conductivity measurements for planning and analysis of agricultural experiments: A case study from Western-Thailand. Geoderma, 267, 220, 2016.

43. JADOON Q.K., ROBERTS E., BLENKINSOP T., RAPHAEL A.J., SHAH S.A. Mineralogical modelling and petrophysical parameters in Permian gas shales from the Roseneath and Murteree formations, Cooper Basin, Australia. Petroleum Exploration and Development, 43 (2), 277, 2016.

44. KAREEM R., CUBILLAS P., GLUYAS J., BOWEN L., HILLIER S., GREENWELL H.C. Multi-technique Approach to the Petrophysical Characterization of Berea Sandstone Core Plugs (Cleveland Quarries, USA). Journal of Petroleum Science and Engineering, 2016.

45. SHAXSON F., BARBER R., Optimizing soil moisture for plant production: the significance of soil porosity. FAO Soils Bulletin 79, Rome, Italy, 2003. 
